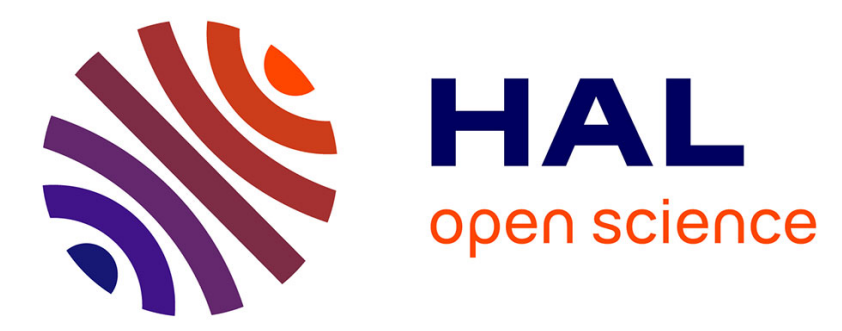

\title{
The role of market forces and food safety institutions in the adoption of sustainable farming practices: the case of the fresh tomato export sector in Morocco and Turkey
}

J.-M. Codron, H. Adanacioglu, M. Aubert, Z. Bouhsina, A. Ait El Mekki, S. Rousset, S. Tozanli, M. Yercan

\section{- To cite this version:}

J.-M. Codron, H. Adanacioglu, M. Aubert, Z. Bouhsina, A. Ait El Mekki, et al.. The role of market forces and food safety institutions in the adoption of sustainable farming practices: the case of the fresh tomato export sector in Morocco and Turkey. Food Policy, 2014, 49 (1), pp.268-280. 10.1016/j.foodpol.2014.09.006 . hal-02163641

\section{HAL Id: hal-02163641 https://hal.science/hal-02163641}

Submitted on 27 May 2020

HAL is a multi-disciplinary open access archive for the deposit and dissemination of scientific research documents, whether they are published or not. The documents may come from teaching and research institutions in France or abroad, or from public or private research centers.
L'archive ouverte pluridisciplinaire HAL, est destinée au dépôt et à la diffusion de documents scientifiques de niveau recherche, publiés ou non, émanant des établissements d'enseignement et de recherche français ou étrangers, des laboratoires publics ou privés. 


\section{WORKING-PAPER - UMR MOISA}

The role of market forces and food safety institutions in the adoption of sustainable farming practices: the case of the fresh tomato export sector in Morocco and Turkey

Codron, J.M. ; Adanacioglu, H. ; Aubert, M. ; Bouhsina, Z. ; El Mekki, A.A. ; Rousset, S. ; Tozanli, S. ; Yercan, M.

WORKING PAPER MOISA 2016-3

Food Policy, vol. 49, Part 1, 2014, 268-280 (Post-print) (c) 1 (1) (3) 


\title{
WORKING-PAPER - UMR MOISA
}

\section{The role of market forces and food safety institutions in the adoption of sustainable farming practices: the case of the fresh tomato export sector in Morocco and Turkey}

\author{
Codron, J.M. ${ }^{{ }^{*}}$; Adanacioglu, H. ${ }^{2}$; Aubert, M. ${ }^{1}$; Bouhsina, Z. ${ }^{1}$; El Mekki, A.A. ${ }^{3}$; \\ Rousset, S. ${ }^{4}$; Tozanli, S. ${ }^{5}$; Yercan, M. ${ }^{2}$ \\ ${ }^{1}$ MOISA, CIHEAM-IAMM, CIRAD, INRA, Montpellier SupAgro, 34000, Montpellier, France \\ ${ }^{2}$ Ege University, Faculty of Agriculture, Department of Agricultural Economics, Izmir, Turkey \\ ${ }^{3}$ National School of Agriculture, Meknes, Morocco \\ ${ }^{4}$ IRSTEA, UR ETBX, 50 Avenue de Verdun, 33612 Cestas Cedex, France \\ ${ }^{5}$ MOISA, CIHEAM-IAMM, CIRAD, INRA, Montpellier SupAgro, 34000, Montpellier, France \\ *Corresponding author: \\ codron@supagro.inra.fr
}

This is the post-print version of the article published as:

Codron, J.M. ; Adanacioglu, H. ; Aubert, M. ; Bouhsina, Z. ; El Mekki, A.A. ; Rousset, S. ; Tozanli, S. ; Yercan, M. (2014). The role of market forces and food safety institutions in the adoption of sustainable farming practices: The case of the fresh tomato export sector in Morocco and Turkey. Food Policy, vol. 49, Part 1, 268-280

doi:10.1016/j.foodpol.2014.09.006

\begin{abstract}
:
Fresh produce growers are the main source of food contamination by chemical pesticides. In their choice of farming practices, producers are influenced by market forces as well as public and private safety regulations - or "macro-drivers" - as opposed to farm-level micro-drivers. Growers respond to their business and regulatory environment by implementing integrated pest management (IPM) and other good agricultural practices (GAP), where profitable through certification schemes. Our paper attempts to analyse the adoption of sustainable farming practices beyond farm and farmer characteristics, focusing on the role of structural and institutional macro-drivers. The empirical research is based on the comparison between Turkey and Morocco, two Mediterranean countries with high export activity in the fresh tomato sector but with contrasting features in terms of both sustainable farming practices and micro/macro-drivers. With regard to the latter, we simultaneously consider supply-side and demand-side aspects (i.e. the requirements of buyers in importing countries). The analysis draws on the literature examining both IPM/GAP adoption and the impact of food safety regulation on firms' strategies. We call on face-to-face interviews with a relatively large number of tomato growers in the main production areas $(\mathrm{N}=86$ in $\mathrm{Morocco}$ and $\mathrm{N}=186$ in Turkey). Our findings show that the average level of sustainable practices is greatly affected by national market and institutional particularities, in particular on the demand side. Moreover the surveys confirm the initial assumption of the major role played by private actors in managing safety risk when there are high business stakes, as in export chains oriented towards rich Western countries.
\end{abstract}

Keywords: Food safety, Pesticides, Integrated pest management (IPM), Good agricultural practices (GAP), Private regulation, Vertical Organization, Fresh vegetables

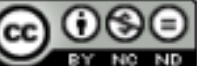




\section{WORKING-PAPER - UMR MOISA}

\section{Research highlights:}

$\checkmark$ There is considerable difference in the scope of sustainable farming practices in the fresh produce value chains of Turkey and Morocco

$\checkmark$ These contrasting situations could be explained by structural and institutional drivers, in particular relating to export markets

$\checkmark \quad$ Private regulation plays a prominent role compared to public regulation when there are high business stakes and strong value chain integration

$\checkmark \quad$ Market forces are an effective spur for adopting government-led best agricultural practices

\section{Résumé :}

La contamination des légumes frais par les pesticides se fait principalement au niveau de la production. Dans leur choix des pratiques agricoles, les producteurs sont influencés par des forces de type macro-économique qui se situent aussi bien au niveau du marché que des régulations publiques et privées. A cela se rajoute une troisième série de forces, qui sont cette foisci spécifiques de l'exploitation et de l'exploitant agricoles et donc de type micro-économique. Les producteurs répondent aux exigences de leur environnement commercial et réglementaire en mettant en œuvre des bonnes pratiques agricoles qu'ils font certifier et des systèmes de gestion raisonnée aptes à lutter contre les ravageurs et maladies. Notre papier vise à expliquer l'adoption de pratiques agricoles durables en mobilisant au-delà des caractéristiques de l'exploitant et de l'exploitation agricoles, les forces structurelles et institutionnelles de type macro-économique. La recherche empirique est basée sur la comparaison de ces forces dans deux pays méditerranéens, la Turquie et le Maroc, qui sont tous les deux d'importants exportateurs de tomate mais qui sont très contrastés au niveau des pratiques d'agriculture durable et des facteurs micro ou macro qui influencent ces pratiques. L'identification de ces forces nous conduit à considérer à la fois le côté de l'offre et celui de la demande aussi bien commerciale que réglementaire. Les théories prises en compte sont celles de l'adoption des standards de bonnes pratiques agricoles ou des systèmes de production raisonnée ainsi que celles de l'impact des régulations de sécurité alimentaire sur la stratégie des firmes. Les données ont été collectées en face à face auprès d'un relativement grand nombre de producteurs ( $\mathrm{N}=86$ au Maroc et $\mathrm{N}=186$ en Turquie). Les résultats montrent que le niveau moyen des pratiques est fortement déterminé par le marché national et par les particularités institutionnelles, en particulier du côté de la demande. Par ailleurs, les enquêtes confirment l'hypothèse du rôle majeur joué par les acteurs privés dans la gestion du risque sanitaire lorsqu'il y a de gros enjeux économiques, ce qui est le cas des filières d'exportation tournées vers les pays riches occidentaux.

Mots-clés : Sécurité des aliments, Lutte raisonnée, Bonnes pratiques agricoles, Régulation privée, Coordination verticale, Légumes frais

JEL : D23, Q13, Q18

\section{Acknowledgements:}

This paper was presented at the 133rd EAAE seminar in Chania (Greece) in June 2013. We are particularly grateful to Michel Petit who commented on an earlier version of this paper and to Imane Bennani who helped us conduct the two surveys in Morocco. Our study was funded by the FP7 Sustainmed Project. For further details concerning the project, see: http://sustainmed.iamm.fr/index.php/publications/project-reports
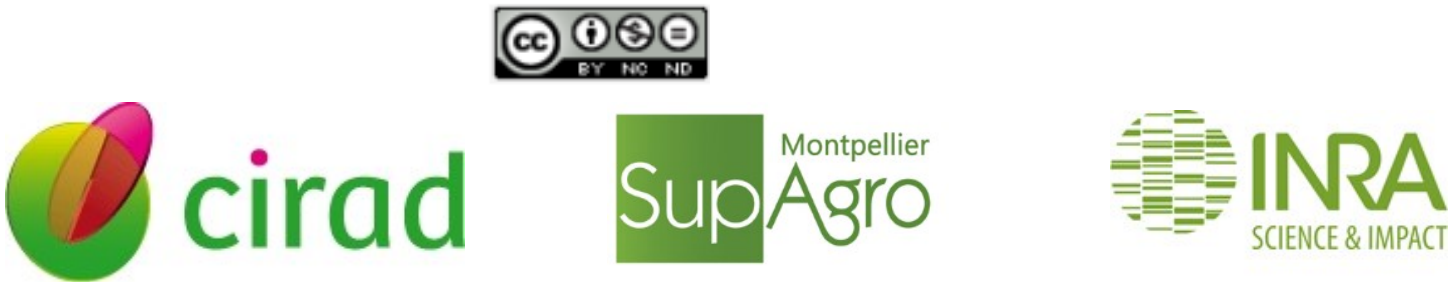


\section{Introduction}

Over the past two decades, fresh produce consumers and public authorities in rich countries have been increasingly concerned with chemical pesticide contamination. Public and private regulation developed to address those concerns is implemented through different types of product and process standards, either mandatory or voluntary, and different types of mechanisms like the "command-and-control" approach, certification, bilateral contracts, collective conventions, etc. Growers are responding to their business and regulatory environment by implementing integrated pest management (IPM) and other good agricultural practices (GAP), where profitable through certification schemes.

The literature on the factors of IPM/GAP adoption is relatively well developed and mostly focuses on individual farmer and farm characteristics, which we refer to as "micro-drivers" (Baumgart-Getz et al. 2012; Codron et al., 2012). Surprisingly, there is almost no research on the impact of "macro-drivers", such as institutions and market forces, on the farmers' decision to adopt an IPM scheme or GAP certificate (one exception is Fernandez and Ferraioli, 1999). Research incorporating macro-drivers such as changes in food safety regulation or crosscountry differences has developed over the last two decades. However, it mostly focuses on the impact on the strategic responses of traders and food companies. In this literature, farmers are sometimes integrated into the whole picture, but only indirectly from the standpoint of food companies, through the analysis of sourcing strategy; no in-depth analysis is provided on the factors influencing the farmers' decisions to adopt sustainable practices.

Our paper endeavours to fill this gap. By drawing on the business literature applied to food safety and by considering the relationship between the farmer and the firm (buyer) and the role it may play in the decision of adoption, it is possible to study the impact of a change in regulations or market forces on a farmer's motivations to adopt IPM practices or a GAP certificate. To this end, we develop a more general framework to analyse the determinants of IPM/GAP adoption and consider, beyond the traditional individual characteristics, a series of macro-drivers, either generic or safety-specific, that may influence farmers' behaviour. Our paper identifies and compares the influence of those micro- and macro-drivers in the fresh tomato sector of two emerging Mediterranean countries with high export activity: Morocco and Turkey. Although quite similar in terms of volume exported and natural conditions (e.g. pest and disease pressure), these countries have very contrasting features of IPM and GAP adoption, rendering the comparison of macro-drivers to explain the differences in adoption very interesting.

Data have been collected for each country in the major region producing fresh tomatoes for export (the province of Souss-Massa-Draa in Morocco and the province of Antalya in Turkey) through face-to-face interviews with a sample of growers (respectively $\mathrm{N}=86$ and $\mathrm{N}=186$ ). $\mathrm{A}$ quantitative analysis based on these data serves to identify the main micro-drivers. However, more attention will be paid to the original aspect of our paper, namely the identification of macro-drivers. As the data is unsuitable to test for the influence of both micro- and macrodrivers simultaneously, we limit our analysis to a qualitative description of the differences in market forces and institutions between the two countries. Since the farmers examined are involved in export chains, two types of macro-drivers will be considered: those specific to the importing country (customers) and those specific to the exporting country.

Special attention is paid both to private regulation in customer countries which may be more restrictive than public regulation for exporting industries - this is the case in some European countries where consumers are greatly concerned by chemical contamination - and to the strength of local institutions and market forces. We assume that in emerging low-income countries with safety-sensitive consumers, there is no real pressure for local state intervention. On the other hand, there is room for local private regulation in response to the high safety requirements of the customer countries. We will thus examine whether local private regulation may work without much state involvement. 
Our hypotheses are that i) the most influential macro-drivers are on the demand side (importing countries) given the low level of government intervention and local consumer safety expectations in the two exporting countries; hence, the higher the level of safety constraints imposed by the demand side, the higher the level of adoption; ii) although much less influential, the macro-drivers on the supply side (exporting country) may in some cases, become significant and help explain adoption; it has recently been the case of Turkey thanks to relatively strong state intervention and greater safety demands on the domestic market.

Drawing on the literature analysing the impact of changes in safety regulation on firms' strategic choices, section 2 presents the conceptual framework used to analyse farmers' safety risk management systems. We distinguish between the micro-drivers usually suggested in the relevant literature and macro-drivers, which influence trading firm purchases from farmers and, indirectly, farmers' decisions to adopt IPM practices and GAP certification. Section 3 presents the micro- and macro-driver analysis methodology. Section 4 describes the contextual features of the tomato chains in the two exporting countries. Section 5 examines the main patterns of risk management and provides summary findings on the micro-drivers of IPM/GAP adoption. Among these factors, special attention will be paid to the farmers' marketing organizations. Section 6 focuses on the country effect by describing the main institutional and structural macro-drivers, highlighting the respective roles of public and private regulation. We successively examine the macro-drivers in the customer countries (demand-side) and in the exporting countries (supply-side). Section 7 concludes, emphasizing the differences in macrodrivers which help explain the gap in IPM/GAP adoption.

\section{Conceptual framework}

The literature on IPM/GAP adoption in the agricultural sector has mostly focused on individual grower/farmer characteristics (micro-drivers). It draws on consumer theory to build household decision models (Fernandez-Cornejo et al, 1994). In this context, it is assumed that growers make decisions concerning IPM techniques or GAP certificates by choosing the alternative that maximizes their perceived utility. The main potential factors of IPM adoption examined are farmer characteristics (age, education, experience, off-farm activity, wealth), which may be considered proxies for managerial ability or risk aversion, and farm characteristics, e.g. economic size, scope, technology, marketing and location (for literature surveys, see BaumgartGetz et al. 2012; Codron et al., 2012). All these variables are essentially individual characteristics. The exception is "location", used as a proxy of natural conditions and of the IPM research and development programs funded by the public and private sector (FernandezCornejo and Ferraioli, 1999). In this paper, the market safety demand is implicitly assumed to be homogeneous across states, while institutional influences are limited to the inter-state variations in IPM subsidies.

Marketing is another variable that could serve as a proxy for the level of quality and safety requirements in the customer country and could therefore reflect the market or institutional macro-drivers influencing the buyer's strategy and, by the same token, the farmer's management of safety risk. To our knowledge, few studies have introduced marketing variables in adoption models to indicate the existence of a marketing contract or cooperative membership. While a couple of studies have focused on IPM techniques to test the effect of forward contracting on farmers' choices (Fernandez-Cornejo and Ferraioli, 1999; McNamara et al., 1991), two other studies have reported that the adoption of GLOBALG.A.P. is positively impacted by the number of years within a farmer group (Asfaw et al., 2010) or membership of a large producer organization (Souza Monteiro and Caswell, 2009). The low frequency of institutional variables is understandable: most studies are conducted for a single country and implicitly assume a single set of public and private safety institutions and the same level of safety requirements. In such conditions, research concentrates on inter-individual heterogeneity, ignoring market and institutional drivers which would have made sense in crosscountry comparisons.

The business literature on food safety issues has developed significantly to analyse the changes or cross-national differences in regulation and their impact on firms' strategies. 
Although primarily focused on the firm (buyer's strategy) and only indirectly on the farmer (suppliers' behaviour), it has not the limitations here above mentioned to take into account the market and institutional drivers. Drawing on a literature that has examined the strategic behaviour of firms in the context of environmental regulation (Barrett, 1991; Rugman and Verbeke, 1998; Khanna, 2001), scholars have provided insights into firms' possible reactions following a change in food safety regulation. In a special issue of the International Food and Agribusiness Management Review on the management of food safety, Henson and Hooker (2001) review the different attempts to model firm-level compliance decisions and summarize the different generic strategic options of compliance based on a cost-benefit analysis as suggested by the literature: opportunism, full or partial compliance, non-compliance, influence on the regulator or the enforcers and exit. Another strand of literature has focused on quality and safety assurance schemes to comply with safety regulation and the private incentives to adopt such management systems (Holleran et al, 1999).

The main changes in regulation considered include the strong development of individual or collective private retailer standards imposed on the suppliers and the main drivers of such development (Fulponi, 2006; Codron et al, 2005). Private regulation has also developed at importer level through the implementation of collective safety control conventions (Codron et al, 2007). Supervised by control agencies, such conventions are typical of the public-private partnerships, or "co-regulation", developed to deliver safer food at lower regulatory costs (Henson and Caswell, 1999; Garcia et al, 2007). Another radical change in safety regulation concerns liability systems, in particular in the UK following the Food Safety Act (Loader and Hobbs, 1999). Comparing the British and French liability regimes and their impact on retailer behaviour, Rouvière and Latouche (2014) highlight the differences in strategic retailer options regarding criminal risk and show that unlike British retailers, French retailers may in some conditions choose to transfer the legal risk to their suppliers, thereby avoiding possible penalties in the event of safety defects. One limitation of this paper is an over-emphasis on the liability risk, ignoring the commercial and reputational risk faced by retailers due to the low level of consumer background information on the real dangers of pesticides for human health and the ensuing risks of manipulation. This commercial risk is often considered by retailers at least as important as the criminal risk, especially in countries with strong consumer activism (Bignebat and Codron, 2006).

Research focusing more specifically on pesticide safety risks is more limited and usually dedicated to the fresh produce sector. It has developed to emphasize the challenges faced by export companies in developing countries to comply with the changes in private and public regulation in customer countries, in particular the private standards of modern retailers in the European Union (Garcia et al, 2004; Jaffee and Masakure, 2005; Narrod et al, 2008). Given the major contribution of farmers to chemical contamination, the analysis has addressed the supplychain issues of exporting companies and the need to restructure the supply chain by implementing GAP standards and developing vertical and horizontal integration to comply with increasingly stringent customer quality and safety requirements. While private regulation may provide a significant contribution to the success of these exporting companies (Garcia et al, 2004), public institutions are often perceived as potential facilitators despite not playing a major role in the success of the export activity. A number of crucial questions have been raised such as the need to upgrade a sourcing organization as soon as exporters decide to include safetyconscious customers in their portfolio (Jaffee and Masakure, 2005), the risk of exclusion of small-scale farmers in developing countries like Kenya, Turkey or India, the advantage of collective action at farm marketing level to coordinate with buyers efficiently (Narrod et al, 2008) and the need for enhanced business culture and tight coordination along the entire food chain when retailers are very demanding in terms of quality and safety (Garcia et al, 2004). However, in all these cases, the analysis focuses on the exporter's strategy, in particular the sourcing strategy, but not from the farmer's standpoint. The literature is limited in that no in-depth analysis has been conducted to explain differences in IPM or GAP adoption.

Our paper attempts to overcome these limitations by bridging the two bodies of literature with a view to providing an extended framework to analyse the factors driving the adoption of IPM techniques and GAP certificates. This is particularly relevant when comparing the macro-drivers 
influencing farmers' decisions across countries. By linking the farmer and the buyer and by addressing coordination issues, it becomes possible to consider the macro-drivers impacting the firm's behaviour and possibly also the farmer's. As demonstrated by many scholars in supply chain management and new institutional economics, the impact of macro-drivers on farmers' decisions will increase with the degree of integration or coordination within the supply chain. Given the low level of market incentives for safe products and the high level of transaction costs to measure the level of pesticide residues or IPM techniques, the need for vertical integration increases with the level of safety demands. Consequently, the higher the degree of coordination in the supply chain, the greater the motivation for the supplier to adopt IPM techniques. Conversely, and given the low market incentives for safe products, spot markets or informal agreements do not provide farmers with strong motivation to adopt IPM techniques. Research findings are more controversial as to whether GAP certificates complement or substitute marketing contracts. However, there is a consensus that the adoption of GAP certificates increases with the level of final safety requirements. In some cases, like GlobalGAP, this adoption may even become a condition to access some countries.

Figure 1 : Determinants of IPM/GAP adoption : micro and macro drivers

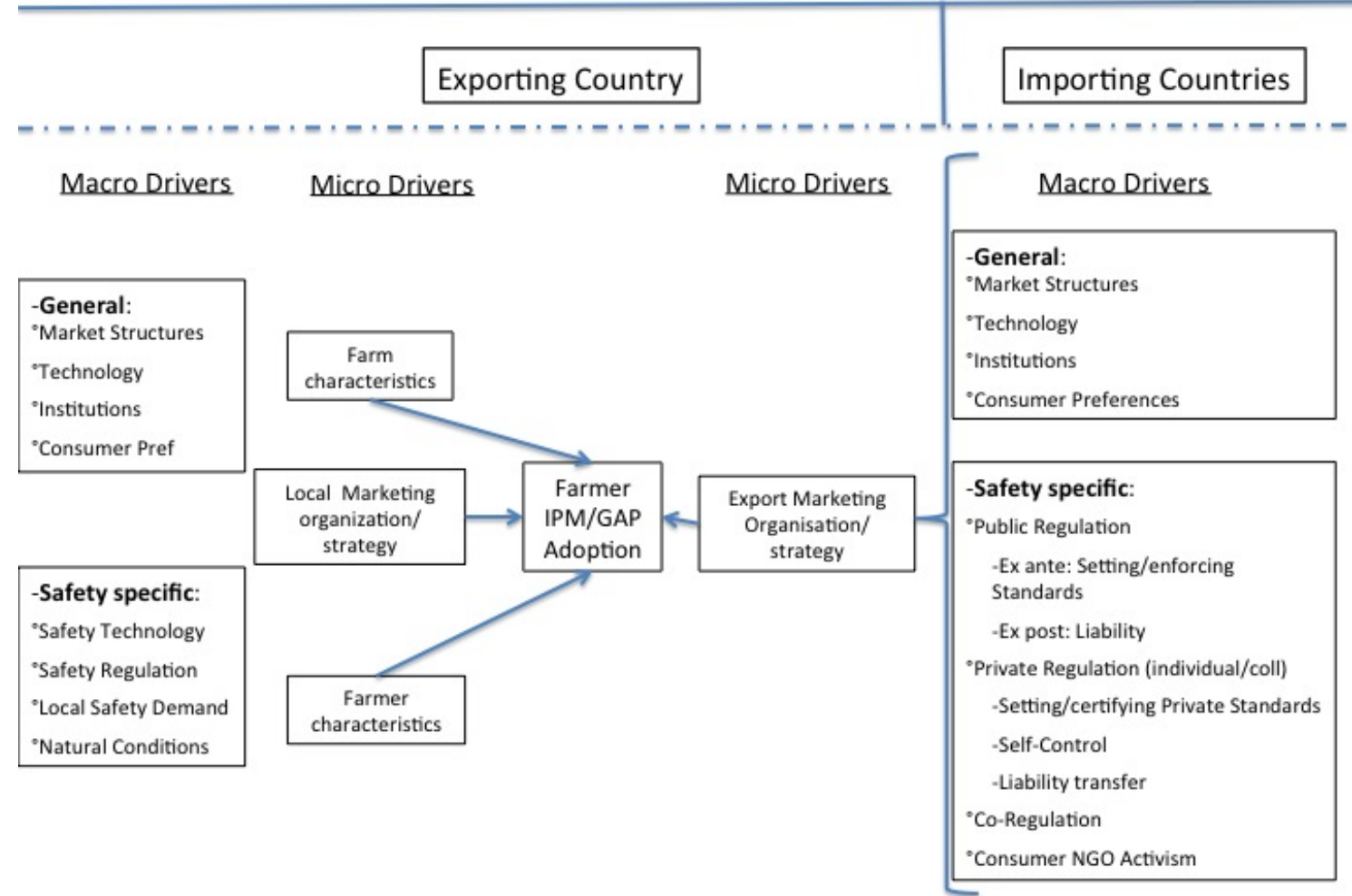

In the event of exporting countries, a clear distinction must be made between the macro-drivers in the importing countries (demand side) and in the exporting country (supply side). On the demand side, there may be numerous customer countries with specific safety requirements, market forces and institutions influencing the export chain. Different strategies exist to comply with this diversity such as aligning the safety risk management system with the requirements of the most demanding country. Another alternative is to respond individually to each requirement. To summarize, we present an analysis grid with the macro-drivers of the most safety-conscious customer country in Figure 1. These macro-drivers are generic or safety-specific, structural (technologies, market forces, industry and retail structures, consumer preferences) or institutional (public and private regulation). With regard to safety regulations, we can differentiate between setting the rules (public and private standards, policy measures, etc.) and enforcing the rules. Drawing on Henson and Caswell (1999), we identify different systems of safety control: ex-ante direct regulation and ex-post product liability on the public side, selfregulation and certification of private standards on the private side. Two other powerful 
mechanisms should be added on the private side: liability transfer (Rouvière and Latouche, 2014) and consumer activism (Bignebat and Codron, 2006).

Some macro-drivers also influence IPM/GAP adoption on the "supply side", although to a lesser extent. These drivers concern the natural environment (pest and disease pressure), country structures (export markets, industry market structure, consumer preferences or expectations) and institutions (public and private regulation). Public regulation includes direct and indirect safety-specific measures: i) direct governmental measures aimed at promoting IPM adoption (such as extension or training programs, financial incentives or bonuses) and controlling for safety performance at all levels of the chain and ii) indirect policies designed to develop and modernize structures (by increasing the number of and upgrading laboratories conducting pesticide residue analysis). Private regulation includes domestic supermarket safety requirements and chain organization to improve safety performance, for instance through thirdparty or industry control.

\section{Methodology}

The paper draws on an EU-funded research project examining the impact of changes in EU safety regulations on the developing Mediterranean country fresh produce export chains. In this section, we provide information on the methodologies used for the empirical studies.

In order to characterize sustainable farming practices and identify the individual factors influencing them, first-hand data have been collected at greenhouse level through face-to-face surveys with 86 farmers in Morocco and 186 farmers in Turkey (see section 5). Data collected on greenhouse practices include the rational use of pesticides (such as scouting, monitoring and recording treatments), integrated pest management (IPM) and related alternatives to pesticides such as bio-control and pheromone traps, as well as certifications of good agricultural practices. In the case of Morocco (province of Souss-Massa-Drâa), we considered two proxies of advanced sustainable farming practices: first, whether or not producers use biological auxiliaries to control harmful insects and second, whether or not they are GLOBALG.A.P.certified and, for those who are certified, the timing of adoption. The detailed methodology and results of the surveys are presented in Aubert et al. (2013).

In the case of Turkey (province of Antalya), only a few growers use biological auxiliaries or are GLOBALG.A.P.-certified. While greenhouses are simple structures covered with glass or plastic and crop technology is still elementary (almost no soilless farming although drip irrigation is generalized), pest and disease management is still for the most part basic (Codron et al., 2012). Several techniques can be adopted to keep the pest population below economic injury level (Kogan, 1998; Fernandez-Cornejo, 1996). In the Turkish case, eleven practices are considered: the use of resistant varieties, yellow sticky traps, blue traps, pheromones, curtains for doors, weeding inside and outside the greenhouse, harvest wall washing and spraying, biological auxiliaries, the elimination of first contaminated plants and the existence of footbaths at each entrance to the greenhouse (table 1). Based on these eleven practices, three levels of adoption (high, medium, low) are used to analyse the factors influencing IPM adoption. From the sample of 186 growers, 40, 96 and 50 growers implement "high", "intermediate" and "low" IPM practices respectively.

In addition to farm surveys, a qualitative analysis aims to provide valuable insights into the influence of structural and institutional macro-drivers on grower adoption (see section 6). The analysis is based on second-hand data collected from reports, grey literature, databases, Internet and meetings with experts and stakeholders in the fresh fruit and vegetable chain. Considering a time-span of several decades, it identifies two periods: i) a first period with most changes in safety institutions related to customer countries and ii) a second period starting in the mid-2000s with some emerging public regulation in the exporting country. The qualitative analysis does not claim to be exhaustive or to assert that the drivers are the most important ones. It draws on the business and supply chain literature in the food safety domain and assumes some independence between micro- and macro-drivers concerning their influence on grower adoption. 


\section{The context: tomato value chains in Morocco and Turkey}

Turkey and Morocco are among the world's leading tomato production and exportation countries. Turkey's production totals about 10 million tons (including tomatoes for processing) while Morocco's production is over 1 million tons. Morocco has the longest experience with exports while Turkey, whose tomato exports were almost zero in the 1970s, has become a major exporter reaching the same level as Morocco in the 1980s. Since the 90s, exports in both countries have increased two or threefold (figure 2).

Figure 2. Morocco and Turkey tomato exports (in tons and value).
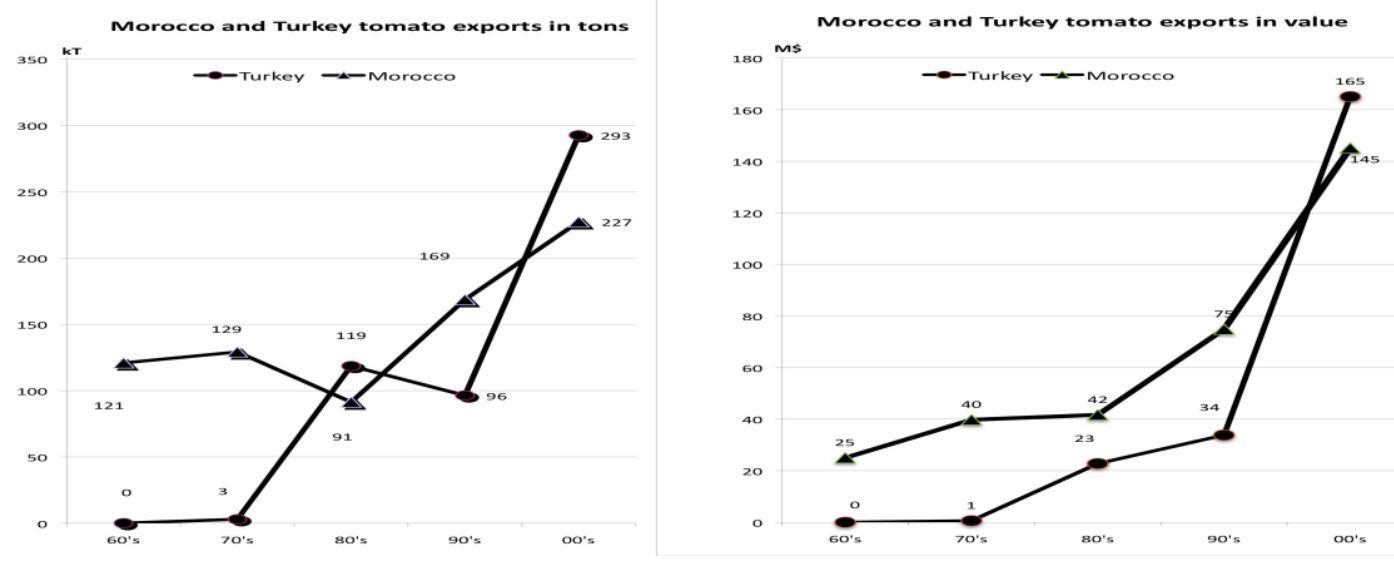

\subsection{Morocco}

Morocco exports tomatoes in the off-season (early production), almost exclusively from the Souss-Massa-Drâa province in south-west Morocco. This province accounts for about $60 \%$ of national tomato production and $80 \%$ of national greenhouse production. The domestic market is supplied with non-export-oriented seasonal production and the discards of the export-oriented early production.

Ninety percent of Moroccan exports of fresh produce are oriented towards Europe where the main concern of consumers is chemical contamination by pesticides used in the production process. This concern has become much more marked over the last two decades. For a long time (from the 1960s to the 1980s), exports varied between 100,000 and 150,000 tons. From the mid-1990s, Moroccan exports began to climb, reaching an average of 200,000 tons at the beginning of the new millennium and 250,000 tons in the mid-2000s. In recent years, this growth has accelerated and exports have now risen above 400,000 t. The recent rapid increase is primarily due to better productivity in the standard loose tomato segment and to the development of new small-sized tomato segments (cherry, cocktail).

France is by far the main market, accounting for about $75 \%$ of total volume exported. Significant developments can also be seen in trade towards Spain, the UK, Switzerland and Russia while exports to Italy, the Netherlands, Slovakia and Germany each still account for less than $1 \%$ of total volume. Morocco has signed several agreements with the European Union. The most recent negotiations were completed in 2012, reinforcing Morocco's preferential access to European markets for several agricultural products. The main preference is for tomatoes. The Moroccan quota is currently set at 233,000 tons with a possible additional quota of 28,000 tons and within the next four years, the quota is scheduled to increase by 52,000 tons. The minimum entry price for Morocco is considerably lower than for other countries. Following successful negotiations between Morocco and the EU in 2003, it was decided to apply a general framework of tariff contingency to tomatoes imported from Morocco for the period running from October to April, with a preferential entry price of $€ 46.1 /$ ton and an ad valorem duty of $0 \%$. Above this 
contingency, Most Favoured Nation status is applied (Goetz and Grethe, 2009; Emlinger et al., 2010).

In terms of vertical organization, three types of actors may be considered in the tomato export chain (right-hand side of figure 3): growers, packers and exporters. According to APEFEL (Moroccan Association of Fruit and Vegetable Exporters-Producers), about 500 tomato growers supply the Moroccan export chain. A vast majority of them is located in Souss-Massa-Drâa province, the main region for early vegetable production. According to our survey, growers can be divided into three categories: i) contractors, who deliver tomatoes to private packing houses in which they hold no stake; ii) cooperators, who are members of a cooperative station; and iii) integrated producers, who own both greenhouse and packing units (Aubert et al., 2013).

Eighty four fruit and vegetable packing plants have been identified in the Souss-Massa-Drâa region (APEFEL, 2010-2011). Packing plants negotiate export quotas with the government and provide technical assistance and information to growers concerning pesticides, certification and markets. A survey of the 30 most important packing plants (Aubert et al, 2013) shows that there are different legal statuses and patterns of vertical organization: eight are cooperatives while the remaining 22 are private entities. Among the latter, 8 are integrated greenhouse packing plants while 14 are supplied by multiple independent growers.

Figure 3. Marketing chains for loose tomato production in Morocco.

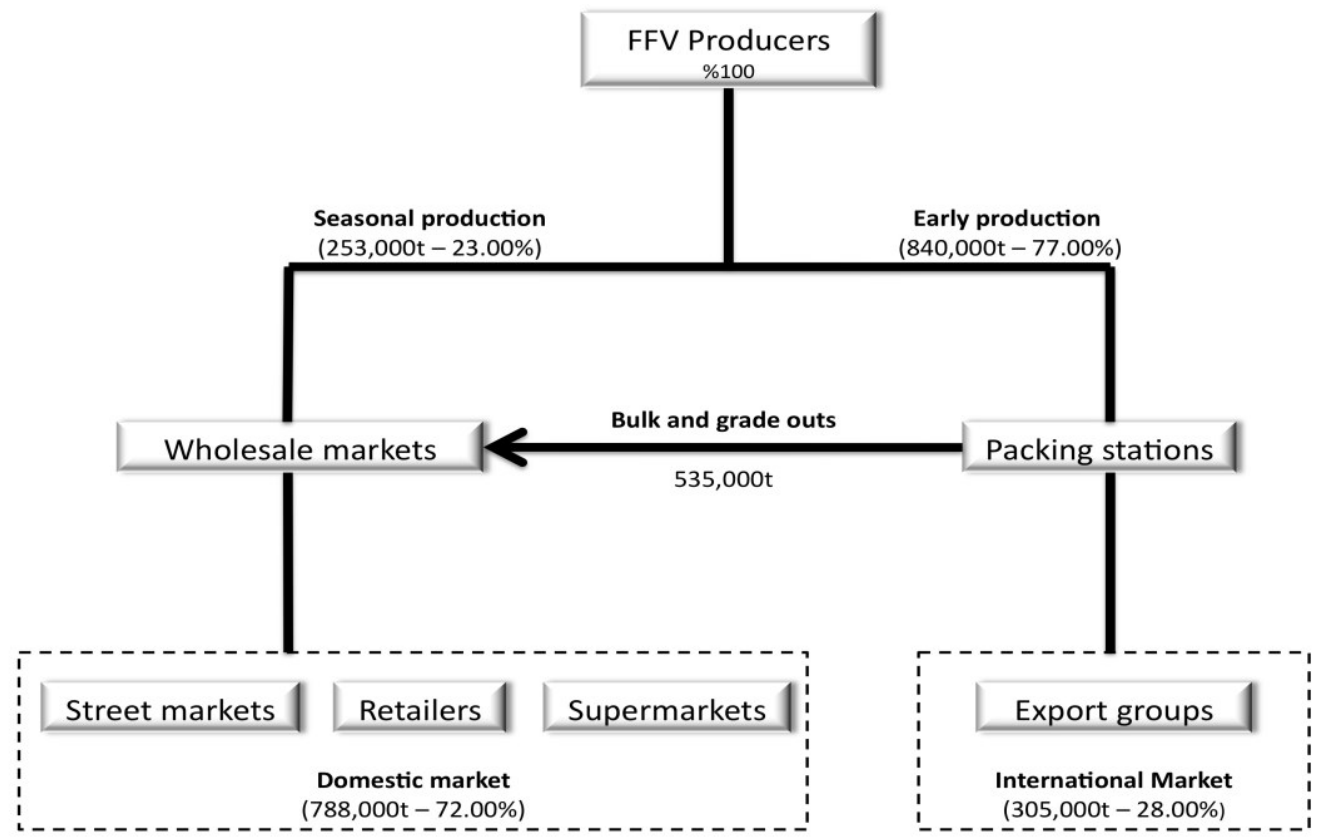

Statistics: CGDA (2011).

There are 15 exporters in Morocco. Their role is i) to ensure the provision of export services, particularly logistics and transportation, and ii) where necessary, to aggregate consignments in a single marketing strategy. Ninety percent of Moroccan tomato exports transit through French importers. According to a survey carried out by UBIFRANCE (2005), three main types of exporter can be distinguished in terms of vertical integration: i) export groups such as Maraissa (Azura), Rosaflore (Idyl), Doche (Matysha) and Delassus which are fully vertically integrated, from production to import activities abroad. Such groups are characterized by a mixed structure of both European and Moroccan capital. They have platforms in Spain or France and enjoy full control over their export activities; ii) export groups like Les Domaines Agricoles, Soema (Avryl) and Armona which are only integrated backwards into production, either through ownership or contracting. With no forward integration into import activities, they mainly sell their products 
through French importers; iii) export groups such as OCE (Office Chérifien des Exportations) and Salam which are not integrated, either forwards or backwards, thereby acting as service providers.

\subsection{Turkey}

In 2012, Turkish production of fresh tomatoes, excluding tomatoes for industrial use, totalled 7.8 million tons, nearly 3 times higher than the volume of production recorded in $1984^{1}$. Fresh tomato exports account for only $8 \%$ of total production. Tomatoes are primarily produced in both western Anatolia (Marmara and Aegean coasts) and southern Anatolia (Mediterranean coast). This regional specialization is even more apparent with regard to tomato production under protective covers (Tuzel et al., 2008, 2006). Antalya province totals nearly $40 \%$ of the national surface area for vegetable production under protective covers. Around $50 \%$ of the Antalya production is oriented towards foreign markets (Ministry of Agriculture, 2010). The main destinations for Turkish fresh tomato exports are the Russian Federation (55.7\%), the EU $(9.0 \%)$, Iraq (7.2\%), Ukraine (5.7\%) and Saudi Arabia (5.2\%), while Bulgaria (3.2\%), Romania $(2.8 \%)$, Poland $(0.9 \%)$ and Germany $(0.8 \%)$ are the main importers in the European Union (Ministry of Agriculture, 2010). Besides a drastic increase in volumes exported, the last two decades have also seen a drastic increase in value exported (figure 2) due to a radical shift in customer portfolio with Russia and new EU members becoming the dominant customers and Saudi Arabia and MENA countries reducing their imports from Turkey considerably.

Figure 4. Marketing chains for greenhouse tomato production in Antalya region Source: Our survey of Antalya growers (N=186). Year 2011.

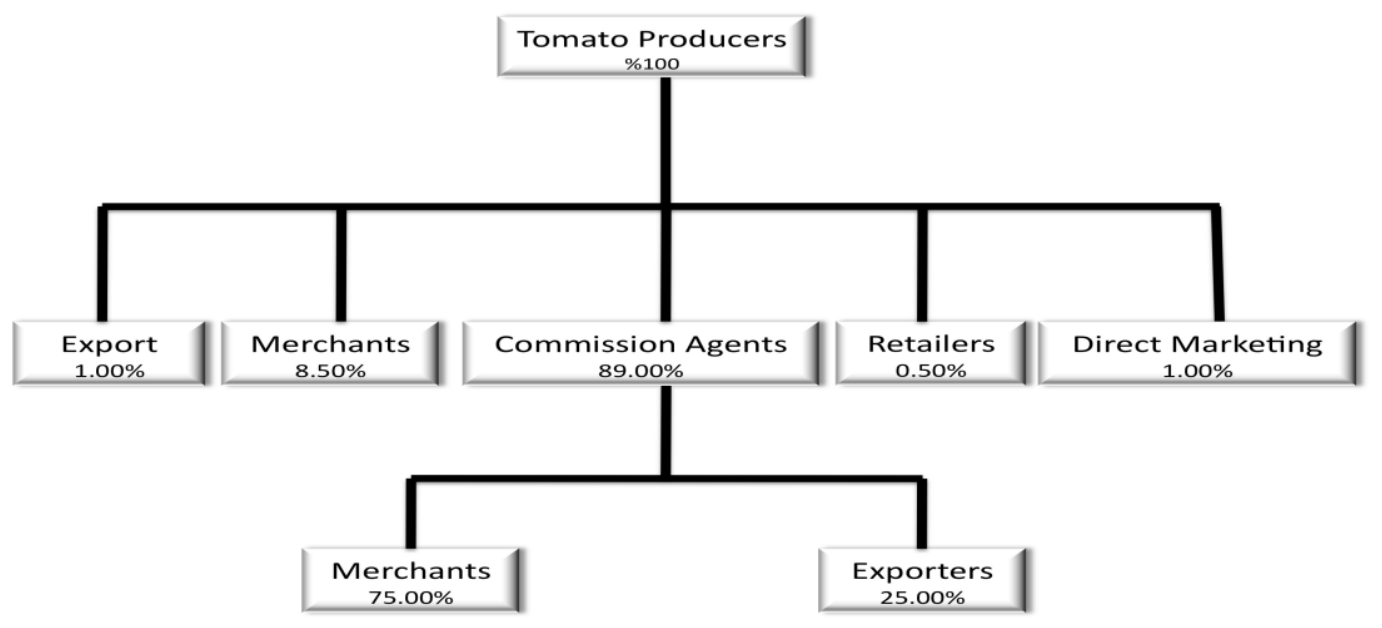

Fresh produce is still largely marketed through open markets challenging supermarket and hard-discount chains, with an estimated $80 \%$ of the market share for FFV. Nevertheless, the shares of large-scale retailers are steadily increasing with regard to FFV marketing. Of the produce bought by commissioners, $75 \%$ is sold on domestic markets while $25 \%$ is sold to export firms. No marketing union of producers has been established in the region. The Wholesale Markets Law (Law 80, Decree 552), which came into force in 1995, aimed to improve the organization of the domestic fresh produce market by establishing commission agents who made transaction controls easier. Of our sample farmers, $89 \%$ sell their produce exclusively through the commissioners in the city hall whereas the remaining $11 \%$ sell via merchants, export firms and retailers or by selling directly to consumers (Figure 4).

\footnotetext{
${ }^{1}$ http://tuikapp.tuik.gov.tr/bitkiselapp/bitkisel.zul
} 


\section{Sustainable farming practices and farm-level drivers}

In this section, we present the findings of our grower surveys in the two main tomato-exporting regions of Morocco and Turkey. After comparing the average level of IPM/GAP adoption in the two countries (table 1), we show how farm/farmer characteristics and market organization influence adoption in each country.

\subsection{Comparing the use of sustainable farming practices in the two countries}

Table 1. Dissemination of sustainable farming practices in Moroccan and Turkish tomato greenhouses.

Source: authors' surveys of growers in Souss-Massa-Drâa and Antalya (N=272). Year 2011.

\begin{tabular}{|c|c|c|c|}
\hline Category of practices & Pest management patterns & Turkey & Morocco \\
\hline \multirow{8}{*}{$\begin{array}{c}\text { Rationale } \\
\text { Chemical } \\
\text { Spraying Management }\end{array}$} & High monitoring frequency $>2 /$ week & $79 \%$ & \\
\hline & Own plant observations ("head farmer & $41 \%$ & $100 \%$ \\
\hline & Private/public consultancy for treatment & $41 \%$ & $17 \%$ \\
\hline & Autonomy from input supplier in treatment & $8 \%$ & $74 \%$ \\
\hline & Spraying delay before harvesting & $99 \%$ & \\
\hline & Treatment recording & $76 \%$ & $99 \%$ \\
\hline & Treatment recording on computer & $3 \%$ & $35 \%$ \\
\hline & Residue self control plan & - & $16 \%$ \\
\hline \multirow{11}{*}{$\begin{array}{c}\text { Integrated } \\
\text { Pest } \\
\text { Management } \\
\text { IPM }\end{array}$} & Resistant varieties & $97 \%$ & $100 \%$ \\
\hline & Yellow traps & $88 \%$ & $100 \%$ \\
\hline & Elimination of contaminated plants & $87 \%$ & $100 \%$ \\
\hline & Curtains for doors & $87 \%$ & $100 \%$ \\
\hline & Weeding & $76 \%$ & $100 \%$ \\
\hline & Equipment cleaning & $75 \%$ & $99 \%$ \\
\hline & Wall spraying & $60 \%$ & $97 \%$ \\
\hline & Blue traps & $34 \%$ & $63 \%$ \\
\hline & Pheromones & $24 \%$ & $97 \%$ \\
\hline & Footbath & $17 \%$ & $86 \%$ \\
\hline & Biological auxiliaries & $3 \%$ & $71 \%$ \\
\hline \multirow{4}{*}{$\begin{array}{c}\text { Integrated } \\
\text { Crop Management } \\
\text { ICM } \\
\text { Management } \\
\text { ICM } \\
\end{array}$} & Bombus bees & $96 \%$ & \\
\hline & Soil water in excess control & $90 \%$ & $63 \%$ \\
\hline & Rotation & $34 \%$ & \\
\hline & Climate control automation & $4 \%$ & \\
\hline \multirow{5}{*}{$\begin{array}{c}\text { Label, } \\
\text { GAP certificate }\end{array}$} & GAP certification & $4 \%$ & $83 \%$ \\
\hline & GLOBALG.A.P. for more than 5 years & $0 \%$ & $53 \%$ \\
\hline & GLOBALG.A.P. option 2 (group certification) & $0 \%$ & $40 \%$ \\
\hline & Tesco certification & $0 \%$ & $9 \%$ \\
\hline & AB certification & $0 \%$ & $3 \%$ \\
\hline
\end{tabular}

As expected, given the earlier and greater exposure of Morocco to customers making safety demands, Moroccan growers in the Souss-Massa are much more advanced in safety risk management than growers based in Antalya province. While basic IPM practices such as frequent pest and disease scouting, compliance with spraying deadlines before harvesting, treatment recording, the use of resistant varieties, yellow traps and insect curtains for doors and openings, the elimination of contaminated plants, equipment cleaning and wall washing have been adopted by a vast majority of growers in both countries, only a minority of Turkish growers are familiar with practices already well-established in Souss-Massa such as the use of pheromones, biological auxiliaries and footbaths at each greenhouse entrance. Likewise, only a minority of them ( $8 \%$ vs. $74 \%$ in Morocco) manage to avoid the decisive influence of pesticide 
dealers in their plant protection strategy. Finally, GLOBALG.A.P. certificates - widespread in Souss-Massa - still concern only a few large-scale growers in Antalya.

In conclusion, we can assert that risk management practices are broadly disseminated in both countries, although differences remain in the level of completion and sophistication, Moroccan Souss-Massa growers being much more advanced than Turkish Mediterranean growers. However, although Souss-Massa growers have generally succeeded in reaching the level of their European competitors, notably in France and Spain, potential still exists for upgrading practices, in particular with regard to the use of biological auxiliaries $(29 \%$ of farmers still do not use these), the voluntary implementation of residue self-control plans and the use of computers to record treatments.

\subsection{Farmer and farm characteristics as micro-drivers of adoption}

In Morocco, given the high level of IPM/GAP adoption, two proxies have been used for analysis: the use of biological auxiliaries and the timing for GLOBALG.A.P. adoption (Aubert et al. 2013). While the agricultural area for producers using auxiliaries is about 90 ha, the average for nonusers is 25 ha. The same contrast in farm size can be observed with regard to the timing of GAP adoption. Early adopters are respectively 2.25 and 4 times larger than followers and noncertified farmers. Farmers who implement such management schemes are generally older, better educated and more likely to undertake a second, non-agricultural activity: $72 \%$ of biocontrol adopters report an external activity compared to $50 \%$ for non-users. Similarly, $75 \%$ of early GAP adopters have another source of income while this figure drops to less than $50 \%$ for the others.

These results are consistent with the literature (Baumgart-Getz et al., 2012; Codron et al.; 2012). While results confirm the role of traditional factors influencing the adoption of sustainable farming practices (e.g. farm size, grower education), they also show that vertical organization plays a significant role as $50 \%$ of growers implementing bio-control are integrated producers ( $16 \%$ for non-users); this same over-representation can be found among GAP early adopters ( $51 \%$ versus $27 \%$ for followers and $7 \%$ for the others).

In Turkey, three levels of IPM adoption have been distinguished. Growers demonstrating a "high" level of IPM practices are younger, more educated, less experienced and less likely than other growers to have an off-farm activity. They have larger farms, are less threatened by pest and disease pressure and are more likely to adopt new technologies. They are more specialized in the production of cluster or cocktail tomatoes, get a higher yield and are more likely to use soilless culture and intensive calendar. Moreover, unlike growers with a low level who all sell on traditional markets, they diversify their marketing channels, selling their production to buyers who require farm auditing and some residue controls. In brief, differentiating growers according to their level of IPM practices highlights homogeneous groups with particularities in terms of farmers' characteristics, farm characteristics and marketing channels.

In addition to showing the heterogeneity of IPM practices prevailing in each country, we can also illustrate the differences in individual characteristics between the two countries. The following table compares the average value for the two samples of some important characteristics of farms (farm size, crop specialization and yield, family labour), farmers (farm head and manager education), chain organization (forward integration into packing) and foreign demand in terms of safety (GAP certificate, residue control plan).

Table 2 highlights the major differences between Morocco and Turkey. The average farm in Souss-Massa is of the "corporate" type while in Antalya it is of the "family" type. The greenhouse size of the former is almost one hundred times larger than that of the latter. In Souss-Massa, farm heads have a higher level of education and hire managers with university diplomas, which is far from true in Antalya. As a result of the large greenhouse size, many Souss-Massa farmers have diversified their greenhouse production and have integrated forwards into vegetable packing. This is not the case of Antalya tomato growers who sell on spot markets and are highly-specialized in greenhouse tomato production. Finally, performance 
in terms of tomato yield is significantly higher in the Souss-Massa region $(19 \mathrm{~kg} / \mathrm{m} 2 \mathrm{vs}$. $11 \mathrm{~kg} / \mathrm{m} 2)$.

Table 2: Characteristics of farmers and farms in the two countries.

\begin{tabular}{lll}
\hline Characteristic / Country & Morocco & Turkey \\
\hline Greenhouse size (ha) & $54 \mathrm{ha}$ & $0.7 \mathrm{ha}$ \\
\hline Tomato specialization (\% under greenhouse) & $57 \%$ & $88 \%$ \\
\hline Farms with family labour (\% farms) & $47 \%$ & $98 \%$ \\
\hline Farm head with university education & $37 \%$ & $15 \%$ \\
\hline Manager with university education & $76 \%$ & $2 \%$ \\
\hline Own packing plant & $34 \%$ & $2 \%$ \\
\hline Audit or certificate required by customer & $83 \%$ & $17 \%$ \\
\hline Residue control plan required by customer & $98 \%$ & $9 \%$ \\
\hline Yield of loose tomatoes (kg/m2) & $19 \mathrm{~kg} / \mathrm{m} 2$ & $11 \mathrm{~kg} / \mathrm{m} 2$ \\
\hline
\end{tabular}

Source: authors' surveys of growers in Souss-Massa-Drâa and Antalya (N=272). Year 2011.

IPM/GAP adoption is thus clearly influenced by the individual characteristics of farms, farmers and their marketing channels. Beyond these micro-drivers, country-specific structural and institutional macro-drivers must be taken into account. As already mentioned in the conceptual framework, given that tomato growers are more or less involved in the export chain, the environments in both customer and exporting countries must be taken into account to identify those factors.

\section{Country effect}

In this section, we undertake a cross-country comparison of the country-specific factors influencing the adoption of IPM practices and GAP certificates by growers involved in the tomato export chains of Morocco and Turkey. We assume similar natural conditions in terms of pest and disease pressure between the two regions, as suggested by Hanafi and Papasolomontos (1999) and consider the other "macro-drivers" (market forces and institutions) both on the demand (customer country) and the supply side (exporting country).

\subsection{Country effect on the demand side}

Regarding the fresh produce sector, public authorities in Western and Central Europe or in MENA countries have so far mainly been concerned with chemical contamination. To prevent contamination, importing countries define and control rules concerning both products (MRL not to exceed, forbidden molecules) and production processes. In the case of imported products, public regulation limits to control pesticides residues over the product. Such controls are performed not only at the boarder but also at further stages of the downstream chain, from the importer to the retailer. In the case of locally-grown products, public regulation also aims to control the distribution and use of pesticides and to provide incentives for the promotion of IPM through training or subsidies (for instance EU environmental-friendly operational programs).

Private regulation may also have a strong influence through the implementation of private standards, delegation of control by public authorities to the private sector, voluntary industry conventions or joint regulation by the public and the private sector. Most of the literature on private regulation deals with the implementation of private safety standards, in particular GLOBALG.A.P. which originated in UK with the enactment of the Food Safety Act (1990). Subject to the "due diligence" liability regime, British retailers implemented "Assurance Produce" to better control farmers' practices with regard to safety concerns (Bignebat and Codron, 2006). This farming process certified standard, which has now been adopted by most north European retailers, subsequently became EurepGAP then GLOBALG.A.P. 
Delegation of control has been encouraged by the European 2005 Food Law, which made selfcontrol mandatory at all levels of the chain. To understand why private regulation has developed significantly in the fresh produce sector of the European countries, it is first necessary to stress that chemical contamination of human health is by far the dominant concern ${ }^{2}$ of public authorities and consumers in Europe. Given the low level of risk to consumers' health compared to microbiological risks in the meat or fish sectors, it is easy to understand that the state, in a context of decreasing global budgets, prefers to allocate more control resources to the riskier sectors and offset the lacking resources in the other sectors like fresh produce by delegating control to private actors while retaining minimum supervision. Delegation of control has been amplified by industry voluntary initiatives that have developed to allow for more flexible and less costly control. Examples of such initiatives are the collective conventions or charters of French importers or wholesalers negotiated with the state which are often referred as public-private coregulation (Codron et al, 2007).

Beyond the obligation of implementing self-control derived from the General Food Law, private European players are also faced with the criminal risk derived from the liability regime (Bignebat and Codron, 2006; Rouvière and Latouche, 2014). As mentioned by numerous scholars, liability regimes are often country-specific and may drastically differ between countries, like between UK and France. In the former, liability lies with the retailer if a fault is detected while in the latter, it lies with the first entity to introduce the product into the country: farmers for locally-grown products or importers for imported products. It is worth mentioning that retailers branding products with private retailer brands become the liable entities.

Lastly, chain players are also faced with the commercial risk which potentially develops with consumer suspicion regarding pesticides residues. Retailers are by far the most concerned by commercial risk in the food chain, given the low market share of branded fresh produce (Codron et al, 2005). Such a risk may be much more critical than the criminal risk as soon as there are activists putting pressure on retailers by publishing the results of their own pesticide residue analyses online. Some Northern European countries like the Netherlands, Germany and Austria are greatly concerned by such a consumer pressure, which results in some retailers imposing more stringent rules than the legislation in place and ensuring that their suppliers respect these rules (Levidow and Bijman, 2002; Fulponi, 2005; Bignebat and Codron, 2006). In order to minimize this double risk (criminal and commercial), downstream players (retailers, wholesalers, importers) develop vertical integration in the value chain. Consequently, all upstream players (farmers, shippers, intermediaries, etc.) are involved in managing food safety risks, beginning with the farmers who spread chemicals on their products. While cooperation is desirable in managing the safety risk along the entire chain, competition remains very active given the conflicting interests of the players involved at the different levels. The bottom line of these marketing forces is a high level of interaction along the chain which adds to the private regulation implemented by the downstream players under the more or less active supervision of the State.

Turkey which, until a few years ago, was trading with less safety-conscious countries of the Middle East and Eastern Europe has been much less concerned than Morocco with such a high quality and safety requirements. As shown by an exporter survey, MRL customer rules were not considered a true constraint due to the weak institutions and infrastructures of those countries (Tozanli et al, 2006). Moreover, and as a result of low consumer safety demands, private regulation which could have been implemented by the food industry and retail sector was almost inexistent.

\subsection{Country effect on the supply side}

Given the safety-demand gap between the domestic market and the export market, macrodrivers are often quite different and may be presented separately, notwithstanding some interferences that will be mentioned.

\footnotetext{
${ }^{2}$ Europe pays attention to only a few quarantine pests; none of them concerns the Mediterranean countries of our case study
} 


\section{A. Export market}

Morocco has a long history of export-oriented production, especially in the early vegetables subsector. Public and private players in the Moroccan value chain have long been aware that safety is a key challenge for competitiveness on foreign markets, in particular the markets of the EU. Exporters organize themselves individually and collectively to comply with EU regulations (traceability, MRL and forbidden molecules) and private customers' standards (at the grower level, GAP certificates and extra MRL). Over the last decade, good agricultural practices, traceability and external audits have been widely implemented in Moroccan greenhouses and packing stations as a prerequisite of access to European markets. Supply chains with tight vertical integration have been a key factor in this process.

Efforts to comply with residue constraints are also collective given the potential negative externalities on national reputation that arise when an exporter is controlled at the EU border with an excess of residues (Codron et al, 2003). EACCE (Etablissement Autonome de Contrôle et de Coordination des Exportations), a governmental organization created in 1986 with active participation of the export industry through technical committees, controls residues on exported fruit and vegetables at the packing level and, in some litigious cases, at field level. In 2009/2010, 1,498 samples of vegetables were taken for mandatory analysis. The group of pesticides to be analysed in a sample is decided by the EACCE inspectors, depending on the last pesticides recorded by the producer. It should, however, be noted that the produce is usually exported before the analytical result is known. When non-compliance is identified, the EACCE warns the exporter concerned and stops any future export of produce coming from the same plot of the farm. The EACCE requests an explanation from the non-compliant exporter, including data on traceability and records of pesticide applications, and provides advice to avoid recidivism.

Turkey. A survey of large Turkish export firms (Tozanli et al, 2006) shows that most companies preferred to export to countries with limited safety requirements, such as East and Central European countries, the Balkans and Arab states. Consequently, little attention was paid to safety except by a minority trying to export to EU member states.

A key date for the rise of safety awareness in the fresh produce export industry in Turkey was 2001 , with the rejection of a shipment of Turkish peppers containing excess pesticide levels by European customs officers. While the economic impact was small, the event encouraged all private and public actors to form a national movement aimed at implementing a decisive upgrade in safety standards. This national movement also benefited the domestic market and consolidated the development of the IPM practices initiated in the mid-90s by the Ministry of Agriculture with some funding from the FAO and WB through a research, training and extension programme intended for all growers active in the fresh produce sector, irrespective of the scale of their operations.

Since the beginning of the new millennium, the private sector has exerted considerable pressure on the public authorities to take the necessary steps in order to improve the existing conditions. One initiative has been to invest in private control laboratories, given the lack of public laboratories (40) and qualified expert-engineers specializing in safety control. This lack of infrastructure has led some export firms, in close collaboration with local NGOs (provincial Chambers of Commerce, regional exporters' unions, municipalities) to invest in establishing private control laboratories. This was made possible by the Directive on the Establishment and Operations of Private Food Control Laboratories, issued in 2000, with 50 private laboratories created specializing in pesticide residues.

\section{B. Domestic market}

Traditional retailing still enjoys a dominant market share in both countries $(80 \%$ in Turkey and more than $90 \%$ in Morocco) and is primarily supplied through wholesale markets. Major public initiatives have been launched with a view to modernizing these wholesale markets and the obligation on intermediaries to perform and register any FFV transactions on the wholesale 
market. Such initiatives have been partially successful in developing competition between buyers and enhancing growers' bargaining power. The flipside of such policies is the lack of market incentives for growers to adopt IPM/GAP. In Turkey, where small-scale production (about 0.5 ha greenhouse per grower) is predominant, the wholesale market system aims to ensure improved price transparency and greater bargaining power for small-scale farmers while continuing to be highly regulated. However, it is considered inappropriate to foster technological innovation and promote greenhouse safety practices given the misalignment of market incentives between growers and buyers (Lemeilleur and Codron, 2011). In Morocco, no significant public safety measure has been taken to adapt domestic-oriented production until the last few years. Public regulation was limited to establishing lists of pesticides that could be used to protect fresh produce crops. The first initiatives date back to 2007 with the Food Law and to 2009 with the creation of ONSSA.

Table 3: Pesticide safety risk management: public and private regulation.

\begin{tabular}{|c|c|c|c|c|}
\hline Market forces & \multicolumn{2}{|c|}{\begin{tabular}{|c|} 
Morocco \\
\end{tabular}} & \multicolumn{2}{|c|}{$\begin{array}{c}\text { Turkey } \\
\end{array}$} \\
\hline Demand-side & \multicolumn{2}{|c|}{$\begin{array}{l}\text { Western Europe export-oriented production } \\
\text { European consumers highly sensitive to } \\
\text { pesticide residues } \\
\text { High food safety demanding customers }\end{array}$} & \multicolumn{2}{|c|}{$\begin{array}{l}\text { Eastern Europe and MENA export- } \\
\text { oriented production. Western Europe low } \\
\text { market share } \\
\text { Except for Europe, low food safety } \\
\text { demanding customers }\end{array}$} \\
\hline Supply-side & \multicolumn{2}{|c|}{$\begin{array}{l}\text { Low income, low food safety-conscious } \\
\text { local consumers; some spillover effects }\end{array}$} & \multicolumn{2}{|c|}{$\begin{array}{l}\text { Medium income, low food safety- } \\
\text { conscious local consumers }\end{array}$} \\
\hline $\begin{array}{l}\text { Price gap } \\
\text { between the } \\
\text { two sides }\end{array}$ & \multicolumn{2}{|c|}{$\begin{array}{l}\text { Price differences are usually large and lead } \\
\text { exporters to ignore the domestic market }\end{array}$} & \multicolumn{2}{|c|}{ Price differences are not so large } \\
\hline Regulation & Public & Private & Public & Private \\
\hline Demand-side & $\begin{array}{l}\text { Liability regimes } \\
\text { with country } \\
\text { specificities } \\
\text { MRL control at } \\
\text { each state border } \\
\text { and beyond at the } \\
\text { wholesaler and } \\
\text { retailer levels } \\
\text { General Food law } \\
\text { and mandatory } \\
\text { traceability }\end{array}$ & $\begin{array}{l}\text { MRL control at } \\
\text { importer and retailer } \\
\text { level } \\
\text { State-supervised } \\
\text { industry charters, } \\
\text { GAP standards and } \\
\text { conditions of market } \\
\text { access in Northern } \\
\text { Europe } \\
\text { High pressure of } \\
\text { activists' organizations } \\
\text { on media and retailers }\end{array}$ & $\begin{array}{l}\text { Weak control of } \\
\text { most customer } \\
\text { countries }\end{array}$ & $\begin{array}{l}\text { No private } \\
\text { regulation except } \\
\text { for Western Europe } \\
\text { (but very low } \\
\text { market share) }\end{array}$ \\
\hline Supply-side & $\begin{array}{l}\text { Some public } \\
\text { control of } \\
\text { residues in the } \\
\text { exporting chain } \\
\text { through EACCE }\end{array}$ & $\begin{array}{l}\text { Alignment with } \\
\text { emerging EU safety } \\
\text { demands } \\
\text { High and medium level } \\
\text { of vertical integration } \\
\text { in the exporting chain } \\
\text { Shipper's involvement } \\
\text { in farmer safety } \\
\text { management } \\
\text { Domestic markets are } \\
\text { not a spur }\end{array}$ & $\begin{array}{l}\text { IPM research } \\
\text { dissemination } \\
\text { program (early } \\
\text { 1990s) } \\
\text { but no impact on } \\
\text { the food chain due } \\
\text { to small-scale } \\
\text { farmers } \\
\text { Some investments } \\
\text { in laboratories for } \\
\text { pesticide residue } \\
\text { analysis }\end{array}$ & $\begin{array}{l}\text { Low level of } \\
\text { vertical integration } \\
\text { in the exporting } \\
\text { chains } \\
\text { 2001: pepper } \\
\text { rejection at the EU } \\
\text { border boosts all } \\
\text { player" safety } \\
\text { efforts, like } \\
\text { investments in } \\
\text { private laboratories } \\
\text { (for pesticide } \\
\text { residue analysis) }\end{array}$ \\
\hline
\end{tabular}

Although supermarkets - supported by public liberalization policies - have grown very quickly over the last decade in both countries, their share of the produce market is still low (about $20 \%$ in Turkey, less than $10 \%$ in Morocco). In Turkey, where the potential for high-value domestic chains is stronger than in Morocco (GDP per capita in Turkey is US\$14,517 versus 5,052 for Morocco; IMF 2010-11), large retailers like Carrefour or Tesco try to promote the adoption of IPM schemes and GAP certificates by their suppliers and to increase safety controls on the product. To be successful, such private initiatives must be implemented in marketing channels 
other than traditional ones. Large-scale producers and marketing groups of small-scale farmers could be good candidates. While the former are limited in number and mostly export-oriented, the latter - whose creation has been fostered by the government - are still emerging (Lemeilleur and Codron, 2011). In Morocco, market forces influencing the supply of safe products on the domestic market are quite different. Potentially, the domestic market benefits from the spill-over effects of the export activity which must comply with foreign customers' strong safety requirements. To fully capture the safety added value of products which are initially export-oriented but are discarded and re-oriented to the domestic market for reasons that are not necessarily due to safety defects, supermarkets require supplier coordination. However, supermarkets find it difficult to establish such coordination because of the lack of incentives of most exporters. The price gap between the domestic and export markets is usually so large that most exporters ignore the domestic market.

\subsection{Recent developments}

\section{A. Export market}

Morocco. Although already boasting good safety performance, Morocco must pay attention to increasing safety demands in the European Union and continue upgrading its safety management. Indeed, more constraints have developed on the public side of the customer countries following the harmonization of MRL across EU members and the global revision of the list of molecules. As a result of market diversification towards countries with highly-sensitive customers and influential activist NGOs like Greenpeace, Morocco's private players have also had to comply with more stringent private standards (in terms of molecules and MRLs) than EU public standards. Accordingly, more vertical integration has been needed in export chains.

It is worth noting that, while Morocco continues to be more advanced than Turkey in complying with demanding foreign customers in terms of MRL, it appears to be much less efficient in complying with demanding countries like Russia in terms of pest quarantine. In 2010, 135 cases subject to quarantine were detected on Moroccan produce in Russia (mainly citrus fruits), which is eight times higher than the number of detections from other citrus-exporting countries (Turkey, Egypt, Spain) ${ }^{3}$. Morocco's failure to comply with phyto-sanitary constraints is quite surprising given its success on European markets.

One explanation may be the low capability of the State to manage such issues. Although the government has some experience in controlling pesticide residues through EACCE and its partnership with the export industry, it lacks total experience ${ }^{4}$ in managing phyto-sanitary issues which, moreover, have a stronger dimension of public good. Indeed, while pesticide residue issues can mostly be governed on a private basis thanks to traceability, even though there may be some concern with regard to national reputation, defaulting on a phyto-sanitary constraint (for instance through the introduction of a forbidden pest or virus) has heavy economic consequences for the importing country and triggers severe sanctions like stopping all imports from the exporting country irrespective of which exporter is at fault. Given the prohibitive costs of excluding free-riders and the threat of retaliation from the country of destination which could lead to considerable economic losses for the exporting country as a whole, full state involvement is required in controlling quarantine pests before the products are loaded onto the reefers.

Turkey. Turkey has significantly upgraded the safety levels of its exports for three main reasons. First, there has been a radical change in the customer portfolio with a shift of exports from less safety-conscious countries like MENA countries towards more safety-conscious countries like Russia and Eastern European countries. Second, there has been an increase in safety requirements in the Eastern European countries which have become members of the EU and in Russia and Saudi Arabia where, for the first time in 2009 and 2011 respectively,

\footnotetext{
${ }^{3}$ www.kommersant.com

${ }_{4}^{4}$ ONSSA created in 2009, is in charge of such controls
} 
shipments of fresh tomatoes were rejected at the border for safety reasons. Third, within the perspective of adhesion to the European Union, there is considerable pressure to catch up and converging with EU rules, thereby satisfying the conditions of EU membership. General quality upgrading resulting from this is reflected in the unit value of Turkey, when compared with those of Jordan and Syria, its rivals on the Western Asian market (Codron et al, 2012).

\section{B. Domestic market}

Morocco. On the domestic market, local safety requirements remain low, probably due to the low income and sensitivity of local consumers and to the low market share of supermarkets. However, public authorities have started to regulate the domestic market more consistently. Following the enactment of the Food Safety Law in 2007, a Food Safety Agency (ONSSA) was created in 2009 to avoid duplication and reduce the transaction costs between the different ministries (Agriculture, Health, Interior, Industry and Trade) mandated to control aspects in the fields of personnel hygiene, product weights and fraudulent practices, equipment and plant certification, product quality and instrument calibration. ONSSA is now the main public body in charge of sanitary controls of fresh fruit and vegetables on the domestic market. Its mission is to regulate, implement and control the conformity of products with domestic regulations including standards, labelling and packaging. As the recent Food Safety Law (Act no.28-07) includes requirements for growers, ONSSA plans to introduce inspections of producers. This will effectively mean holding producers and processors accountable for mandatory measures that include farm registration, traceability, internal audits, hygiene and good practice guides. The law also specifies mandatory measures for informing consumers through product labelling.

Table 4: Recent developments in pesticide safety risk management

\begin{tabular}{|c|c|c|c|c|}
\hline Market forces & \multicolumn{2}{|c|}{ Morocco } & \multicolumn{2}{|c|}{ Turkey } \\
\hline Demand-side & \multicolumn{2}{|c|}{$\begin{array}{l}\text { Increasing level of food safety demands } \\
\text { due to market diversification towards } \\
\text { more safety-conscious customers } \\
\text { (Germany, UK, etc.) }\end{array}$} & \multicolumn{2}{|c|}{$\begin{array}{l}\text { Radical shift in customer portfolio. Russia } \\
\text { and new Eastern EU members which have } \\
\text { become the dominant customers, show an } \\
\text { increase in safety demands }\end{array}$} \\
\hline Supply-side & \multicolumn{2}{|c|}{$\begin{array}{l}\text { Almost no evolution in safety demands } \\
\text { from local consumers }\end{array}$} & \multicolumn{2}{|c|}{$\begin{array}{l}\text { Emerging safety demands from medium- } \\
\text { income local customers }\end{array}$} \\
\hline Regulation & Public & Private & Public & Private \\
\hline Demand-side & $\begin{array}{l}\text { MRL } \\
\text { harmonization, } \\
\text { reduction in the list } \\
\text { of authorized } \\
\text { molecules }\end{array}$ & $\begin{array}{l}\text { Private retailer } \\
\text { standards on } \\
\text { MRL more } \\
\text { stringent than } \\
\text { public ones }\end{array}$ & $\begin{array}{l}\text { Main foreign } \\
\text { customers are } \\
\text { increasingly } \\
\text { safety-conscious } \\
\text { in terms of } \\
\text { pesticide residues }\end{array}$ & $\begin{array}{l}\text { Unlike the EU, no } \\
\text { major role of private } \\
\text { players of the } \\
\text { customer country in } \\
\text { the safety domain }\end{array}$ \\
\hline Supply-side & $\begin{array}{l}\text { 2007: Food Safety } \\
\text { Act } \\
\text { 2011: Application } \\
\text { of traceability and } \\
\text { record keeping. } \\
\text { Weak state } \\
\text { capability to } \\
\text { comply with new } \\
\text { quarantine pest } \\
\text { requests }\end{array}$ & $\begin{array}{l}\text { More vertical } \\
\text { integration in the } \\
\text { exporting chain to } \\
\text { comply with the } \\
\text { safety rules } \\
\text { Domestic markets } \\
\text { are not yet a spur } \\
\text { Some emerging } \\
\text { initiatives of local } \\
\text { supermarkets }\end{array}$ & $\begin{array}{l}\text { 2004 : Turkish } \\
\text { GAP regulation } \\
\text { 2010: Food Law } \\
\text { 2012: } \\
\text { Compulsory } \\
\text { traceability } \\
\text { Incentives for the } \\
\text { adoption of GAP } \\
\text { and IPM }\end{array}$ & $\begin{array}{l}\text { Vertical integration is } \\
\text { not easy due to small } \\
\text { farm size and the lack } \\
\text { of incentives of the } \\
\text { wholesale markets. } \\
\text { Cooperatives which } \\
\text { are developing may } \\
\text { help bypass the } \\
\text { traditional } \\
\text { intermediaries. } \\
\text { Emerging safety } \\
\text { initiatives of local } \\
\text { supermarkets }\end{array}$ \\
\hline
\end{tabular}

Turkey. Public safety regulations which were initially export-oriented, now also decisively target the domestic market. Ambitious policy measures to improve the safety and traceability of fresh 
produce are implemented at all levels of the chain. Farmers are the first players concerned, irrespective of the scale of their activity and of whether they are export-oriented. Different measures have been taken since 2009: i) a first regulation introduced in 2009 obliges growers to deal with a public or qualified private consultant in order to buy the necessary chemical products; ii) further regulations which came into force in 2010 and 2011 aim to increase grower awareness of pesticide issues and to develop some form of integrated pest management (IPM). In this way, following the implementation of a new regulation in September 2004, a Turkish GAP was created to cover a wide range of agricultural practices. It is seen as a first step towards the adoption of GLOBALG.A.P. In 2012, the Ministry of Agriculture introduced subsidies for biocontrol provision, insurances and credit for greenhouse producers registered within the System of Protected Cultivation.

New policy measures also concern downstream players. The traceability/safety law (no. 5957 issued in 2012) stipulates that all sellers and buyers of fresh produce are obliged to register online in the city hall system. It also strengthened the existing control system which had been implemented following the 2004 Food Law but was poorly enforced. Consumer complaints which were very scarce until a few years ago, have developed in recent years, helping make public controls more efficient along the entire marketing chain. They have also exposed retailers to the threat of being punished in the event of legal proceedings ${ }^{5}$. Consequently, large-scale retailers have become very careful in their fresh produce sourcing and prefer to buy either from large producers/exporters certified by private labels (GLOBALG.A.P., BRC, Tesco standards, etc.) or from dedicated wholesalers who collect from small-scale growers and are committed to establishing some degree of traceability and to sending residue analyses to the retailer. This is the case, for instance, of Kipa-Tesco which buys from 35 suppliers who are regularly audited, conducts 120 residue analyses per month and traces 50 to $60 \%$ of fresh produce sold. Another outstanding initiative is Migros' partnership established in 2010 with the Ministry of Agriculture with a view to buying certified fresh produce from producers under contract. In 2010,5,000 producers agreed to become partners of this large-scale retailer, obtaining certificates and subsidies (Codron et al, 2012).

\section{Conclusion}

To summarize the findings, we wish to highlight the fact that Morocco and Turkey have contrasting micro- and macro-drivers of sustainable farming practices, which explain the large differences in the practices adopted by tomato growers involved in the export sector in the two countries. Farm size and food chain organization are good examples of contrasting microdrivers: mean farm size of 54 ha in Morocco versus only 0.7 ha in Turkey; high level of vertical integration in Morocco versus traditional market coordination with low incentives for IPM/GAP adoption in Turkey. We find similarly large differences in the structural and institutional macrodrivers of adoption, especially when examining the demand-side and customer countries. While Morocco is faced with high safety requirements from the European Union, simultaneously channelled through public and private regulation, Turkey was until a few years ago little exposed to stringent safety demands and was only concerned by traditional quality requirements. The contrast also exists on the supply side, although to a much smaller extent. While state intervention is weak in the two countries in terms of safety regulation on the domestic market, the level of private regulation on the export market represents a significant difference between the two countries (strong in Morocco versus emerging in Turkey).

In short, our findings show that the management of pesticide safety risks at farm level is simultaneously affected by individual farm and farmer characteristics (including marketing linkages) and by country-wide market and institutional drivers, in particular on the demand side. Moreover, the empirical results confirm our initial assumption of a major role played by private actors in managing food safety risk as soon as there are high business stakes, as witnessed in export chains oriented to rich Western countries.

\footnotetext{
${ }^{5}$ For instance, in 2009, the chief FFV buyer of a large European retailer in Izmir was sued and threatened with prison because of excess residues detected on a batch of pears without traceability to the producer.
} 
Cross-country comparison in the recent period offers some additional findings that allow a more nuanced picture. First, Turkey and Morocco have significantly increased the proportion of their exports towards customer countries with high income and safety-conscious consumers. Therefore, these importing countries continue to be the most powerful drivers of IPM/GAP adoption. Second, local consumers are not yet a real spur, although consumers' complaints have begun emerging. Third, local public regulation is becoming more consistent; this is true in particular for Turkey, within the perspective of adhesion to the European Union. It is also true for Morocco, where public regulation was until recently only a complement to private organization to frame the individual efforts of companies exporting to EU safety-conscious countries. Strong public regulation is now called for to address the phyto-sanitary issues that have emerged due to portfolio diversification, in some new customer countries.

Although the scope of public and private involvement in food safety management is highly country-specific, due in particular to cultural and institutional path-dependencies, it may also be commodity-specific and dependent on the stage of development of the food sub-sector. The case of Turkey, with its significant policy development, illustrates this point. Indeed, while a consistent program of development of IPM practices was already launched in the 1990s, the decisive step in taking policy measures has been taken only recently. This may be explained by the early stage of development of the high-value produce chain in this country, fruit and vegetable farmers having not yet benefited from the momentum of the private sector, like that provided by export players in Morocco.

Taking the analysis of public and private food safety regulations further, it would be interesting to test for statistical independence between micro- and macro-drivers. This is not possible with the data to hand due to the huge differences in farming socio-demographics and structures (farm size in particular) and the large difference in the scope of IPM and GAP practices in the two countries. Another limitation of the study is the low level of vertical integration at grower level in the Turkish tomato industry which prevents a sub-sample of export-focused growers being analysed.

It may be beneficial to increase the number of country studies and, as far as possible, to select countries with similar features in terms of market orientation and farm structures, thereby enabling the contribution of micro- and macro-drivers to the adoption of sustainable farming practices to be identified. It may also be interesting to consider countries characterized by early government involvement in pesticide residue control, such as EU countries.

From a policy standpoint, two relevant issues could be highlighted for further research. In Turkey, there is a need to assess the potential impact of the challenging and promising 2010 public safety regulation and to see to what extent it may influence the adoption of IPM and GAP by smallholders. In Morocco, although advanced IPM practices have been already adopted by most of producers, potential for better compliance with public and private safety standards of foreign customers still exists. Progress may be obtained in the supply chain organization, in particular by reinforcing vertical grower/shipper coordination and developing grower marketing groups. 


\section{Bibliography}

Asfaw, S., Mithöfer, D., Weibel, H., 2010. What impact are EU supermarket standards having on Developing countries export of high value horticultural products? Evidence from Kenya. Journal of International Food and Agribusiness Marketing 22 (3-4), 262-276.

Aubert, M., Bouhsina, Z., Codron, J.-M., Rousset, S., 2013. Pesticides safety risk, food chain organization, and the adoption of sustainable farming practices. The case of Moroccan early tomatoes. 134th EAAE Seminar, Labels on sustainability: an issue for consumers, producers, policy makers, and NGOs, March 21-22, 2013, INRA, Paris, France.

Barrett, S., 1991. Environmental Regulation For Competitive Advantage. Business Strategy Review, 2: 1-15.

Baumgart-Getz, A., Prokopy, L.S., Floress, K., 2012. Why farmers adopt best management practice in the United States: A meta-analysis of the adoption literature. Journal of Environmental Management 96(1): 17-25

Bignebat, C., Codron, J.M., 2006. Organizational innovations and food safety monitoring in the fresh produce industry. INRA Sciences Sociales Recherches en Economie et Sociologie Rurales. 2006, (November 5-6 Entreprises et filières agroalimentaires face à de nouveaux enjeux) : $1-4$.

Codron, J.M., Sterns, J., Reardon, T., 2003. Strategic choices in produce marketing: issues of compatible use and exclusion costs. Journal of Food Distribution Research 34(3):1-12.

Codron, J.M., Giraud-Héraud, E., Soler, L.G., 2005. Minimum quality standards, premium private labels, and European meat and fresh produce retailing. Food Policy, vol. $30, n^{\circ} 3$, 270-283

Codron, J.M., Farès, M., Rouvière, E., 2007. From public to private safety regulation? The case of negotiated agreements in the French fresh produce import industry. International Journal of Agricultural Resources, Governance and Ecology 6(5):415-427.

Codron, J.M., Adanacioglu, H., Aubert, M., Bouhsina, Z., El Mekki, A., Rousset, S.,Tozanli, S., Yercan, M., 2012. Pesticide Safety Risk Management in High Value Chain: the case of Turkey and Morocco. Deliverable $\mathrm{n}^{\circ} 16$, Final Report. FP7 Sustainmed project, Work Package 5.4, May 2012.

CGDA 2011. La situation de l'agriculture marocaine, $n^{\circ} 9$ (November). Rabat, Ministère de l'Agriculture, Conseil Général du Développement Agricole, 202 p.

Emlinger, C., Chevassus-Lozza, E., Jacquet, F., 2010. Fruit and vegetable access to EU markets: Dissecting tariffs faced by Mediterranean countries. Food Policy, 35(6): 599611.

Fernandez-Cornejo, J., 1996. The microeconomic impact of IPM adoption: theory and application. Agricultural and Resource Economics Review 25(149-160).

Fernandez-Cornejo, J., Beach, E.D., Huang, W., 1994. The adoption of IPM techniques by vegetable growers in Florida, Michigan, and Texas. Journal of Agricultural and Applied Economics: 158-172.

Fernandez-Cornejo, J., Ferraioli, J., 1999. The Environmental Effects of Adopting IPM Techniques: The Case of Peach Producers. Journal of Agricultural and Applied Economics 31: 551-564.

Fulponi, L., 2005. Private voluntary standards in the food system: The perspective of major food retailers in OECD countries. Food Policy 31(1):1-13.

Garcia Martinez, M., Poole, N., 2004. The development of private fresh produce safety standards: implications for developing Mediterranean exporting countries. Food Policy 29(3):229-255.

Garcia-Martinez, M., Fearne, A., Caswell, J.A, Henson, S., 2007. Co-regulation as a possible model for food safety governance: Opportunities for public-private partnerships. Food Policy 32(3), 299-314.

Goetz, L., Grethe, H., 2009. The EU entry price system for fresh fruit and vegetables- Paper tiger or powerful marekt barrier? Food Policy, 34(1): 81-93.

Hanafi, A., Papasolomontos, A., 1999. Integrated production and protection under protected cultivation in the Mediterranean region. Biotechnology Advances 17 (1999): 183-203

Henson, S., Caswell, J., 1999. Food Safety Regulation: An overview of Contemporary Issues. 
Food Policy 24 (6), 589-603.

Henson, S., Hooker, N.H., 2001. Private sector management of food safety: public regulation and the role of private controls. International Food and Agribusiness Management Review, 4 (2001), 7-17.

Holleran, E., Bredahl, M.E, Zaibet, L., 1999. Private Incentives for Adopting Food Safety and Quality Assurance. Food Policy 24 (6), 669-683.

Jaffee, S.Masakure, O., 2005, Strategic use of private standards to enhance international competitiveness: Vegetable exports from Kenya and elsewhere, Food Policy, 30, issue 3, p. 316-333.

Khanna, M., 2001. Non mandatory approaches to environmental protection. Journal of Economic Surveys, Vol. 15, No. 3, pp.391-424

Kogan, M., 1998. Integrated Pest Management: Historical Perspectives and Contemporary Developments. Annual Review of Entomology 43: 243-270.

Lemeilleur, S., Codron, J.-M., 2011. Marketing cooperative vs. commission agent: The Turkish dilemma on the modern fresh fruit and vegetable market. Food Policy, 36(2): 272-279.

Levidow, L., Bijman, J. 2002. Farm inputs under pressure from the European food industry. Food Policy, 27(1): 31-45.

Loader, R., Hobbs, J., 1999. Strategic Responses to Food Safety Legislation. Food Policy

24(6), 685-706.

McNamara, K.T., M.E. Wetzstein, Douce, G.K. 1991. Factors Affecting Peanut Producer Adoption of Integrated Pest Management. Review of Agricultural Economics 13(1): 129139.

Ministry of Agriculture 2010. Official Data on Greenhouse of Antalya Region, Regional Directorate of Antalya.

Narrod, C. A., Roy, D., Okello, J., Avendaño, B., Rich, K. Thorat, A., 2009. Public-private partnerships and collective action in high value fruit and vegetable supply chains, Food Policy, 34, issue 1, p. 8-15.

Rouvière, E., Latouche, K., 2014. Impact of liability rules on modes of coordination for food safety in supply chains. Eur J Law Econ 37:111-130

Rugman, A. M., Verbeke, A., 1998. Corporate strategies and environmental regulations: an organizing framework. Strat. Mgmt. J., 19: 363-375.

Sharma, A., Bailey, A., Fraser, I., 2011. Technology Adoption and Pest Control Strategies Among UK Cereal Farmers: Evidence from Parametric and Nonparametric Count Data Models. Journal of Agricultural Economics 62(1): 73-92.

Souza-Monteiro, D.M., Caswell, J.A., 2009. Traceability adoption at the farm level: An empirical analysis of the Portuguese pear industry. Food Policy 34 (1), 94-101.

Tozanli, S., Lemeilleur, S., Codron, J.-M., Aktas, Z., Coudel, E., 2006. Upgrading Quality in Fresh Tomatoes Sector ; characterisation of the post-harvest marketing channels in Turkey. Report for the Ecoponics Research Project funded by the European Union under the 6th Framework; Montpellier, $40 \mathrm{p}$.

Tuzel, Y., Gul, A., Oztekin G.B., 2008. Recent developments in protected cultivation in Turkey. Fao Regional Working Group On Greenhouse Crops In The See Countries pp 75-84

Tuzel, Y., Oztekin, G.B., 2006. Protected Cultivation in Turkey. 6th FAO Regional Working Group Meeting on Greenhouse Crop Production in the Mediterranean Region. pp 68-76

UBIFRANCE 2005. Capacité concurrentielle du Maroc en fruits et Légumes primeurs: stratégies des exportateurs. Rapport d'Etude. Paris, UBIFRANCE. 